\title{
The Media System in the Russian Federation. Selected issues
}

\section{Theories of the media systems}

In the context of the modern media systems, media experts point out to their two main categorizations, the construction of which represents the reflection of media policy: four theories of the press by Siebert, Peterson and Schramm (1956) and three models of the media and policy by Hallin and Mancini (2004) ${ }^{1}$.

In the mid-1950s, during the Cold War, US researchers Fred S. Siebert, Theodore Peterson and Wilbur Schramm suggested periodization of the media systems reflecting the character of political systems. Thus, the totalitarian media system referred to communism while dictatorship corresponded with the authoritarian media system. Democracy, on the other hand, corresponded with the liberal system and so-called system of media social responsibility ${ }^{2}$.

The totalitarian media system was characterized by the fact that mass media played mainly propaganda role resulting from the assumptions of the communist ideology according to which, all aspects of reality should be subject to the inspection of party and state institutions involving politics, economy, social relations and finally, culture. That type of interconnectivity was also characterized by the lack of private ownership of the media establishments as well as strict, official preventive censorship. The authoritarian system was also characterized by the clear dominance of state apparatus and a single dictator over the society, above all, limited to the political sphere. That is why, the authoritarian system allowed for, apart from the state media, the functioning of private mass media loyal to the dictatorial regime. They were controlled by restrictive legisla-

1 The two other categorizations are: three models of the media systems (2013) and four empiric types of the western media systems (2014), B. Dobek-Ostrowska, Między politologia i komunikologia. Razem czy osobno? Przypadek studiów porównawczych nad relacjami polityki i mediów w Europie Środkowo-Wschodniej, „Politeja” 2015, no. 4 (36), p. 29-31.

2 Media masowe na świecie. Modele systemów medialnych i ich dynamika rozwojowa, edit. B. D. Ostrowska, Wrocław 2007, p. 36-38. 
tion, licensing system of the broadcasting and publishing activity, preventive censorship and repressive apparatus. One of the aims of media existence was to strengthen the dictatorship power through the support for the authoritarian power or maintenance of neutrality. The above mentioned rules may be expressed in a single statement: strong authority - weak media. In the liberal system, the main objective of the mass media was to earn money for the owners and implement the function of "the fourth power" towards the judiciary, the executive and the legislative. The model of media social responsibility emphasized the function of the media as the space for the public debate on important social issues ${ }^{3}$.

In the second categorization from the turn of 20th and 21st century, developed by Daniel C. Hallin and Paolo Mancini, the authors focused on the differences of the media systems only in democratic states. It seemed obvious that after the collapse of communist regime and the series of collapses of authoritarian censorships, liberal democracy characteristic for the Eurasian civilization, will become a prevailing model of state organization in other parts of the world as well. The authors analyzed the state media systems according to the four criteria: the development of press markets with the special attention paid to the degree of the press market development, the level of political parallelism, that is, the degree and character of connections between the media and political parties, the level of journalistic professionalism and the degree and character of the state interference with the media system. Having researched the features of the media systems of the United States, Canada and sixteen member states of the European Union, the following three models were distinguished: liberal (North-Atlantic), democratic corporatism (North and Central European) and polarized pluralism (Mediterranean or Southern European $)^{4}$.

The newest categorization of the media systems that refers exclusively to the Central - Eastern European countries has been suggested by Bogumiła Dobek - Ostrowska. The main factors determining the models of media systems are as follows: striving to strengthen authoritarian tendencies in Belarus and Russia, the level of democracy development in other states of the region and finally, the state of freedom of the media. In order to determine those factors, the following scientific studies and data obtained from the five rankings have been used: Democracy Index produced by The Economist Intelligence Unit, Press Freedom Index established by Freedom House, Press Freedom Index produced by Reporters Without Borders, the level of GNP per capita, and finally, the Internet accessibility ${ }^{5}$.

\section{Ibid.}

4 D. C. Hallin, P. Mancini, Systemy medialne. Trzy modele mediów i polityki w ujęciu porównawczym, Kraków 2007; Media masowe na świecie...., p. 44-55.

5 B. Dobek-Ostrowska, Między politologia i komunikologiq..., „Politeja” 2015, no. 4 (36), p. 31-35; comp. A. Školany, Research on Mass Media i Central/Eastern Europe on Southern Europe in Comparative Analysis, [in:] Comparing Media Systems in Central Europe. Between Commercialization and Politicization, edit. B. Dobek-Ostrowska, M. Głowacki, Wrocław 2008, p. 27-40; Jakubowicz K., 
The collected data allowed to distinguish the four models of media systems: liberal - hybrid model (Lithuania, Latvia, Estonia, Poland, Slovakia, Czech Republic and Slovenia), model of politicized media (Hungary, Croatia, Serbia, Bulgaria and Romania), media model in the phase of transition to democracy (Ukraine, Moldova, Bosnia and Hercegovina, Montenegro, Kosovo and Macedonia) and authoritarian model (Belarus and Russia) ${ }^{6}$. The features of the last model are to a significant extent compatible with the authoritarian model developed in the mid-1950s by Siebert, Peterson and Schramm. The political system is characterized by the lack of competition. Power is exercised by a single strong leader. The system is highly centralized. Political, business and media elites are integrated through financial and political benefits. The main mass media are extremely politicized. Their main objective when it comes to information and interpretation broadcasting, is to support a state leader through dissemination of propaganda content that facilitates the control over the society. Criticism of the government, characteristic for the function performed by "the fourth power" in democracies, is in an informal way prohibited. Administrative and repressive apparatus constitutes an effective tool to ensure this?

\section{Historic context}

The media system of majority of Western countries possesses some common features which evidently result from identification and evolution of the democratic system accompanied by the development of capitalist economy. Independence and commerciality are one of the most important characteristics of this type of mass media. Looking from the perspective of these criteria, Russian media had totally different conditions of development in the historic, political and economic context. Even the establishment of the first type of media - the printed one, was arranged by "the highest authority" as an element of the Tsar's policy. By virtue of the decree of Peter the Great of December 1702,the first Russian newspaper "Wiedomosti" (Russian: «Ведомости») was established, in which the Tsar's decrees were printed and discussed. The newspaper had primarily propaganda character clarifying the innovative nature of the sovereign's reforms as regards the internal and external policy of the state ${ }^{8}$. The beginnings of the formation of Russian media system considerably differed from the Western media system in which the first newspapers were published mainly on private initiative and served commercial and trade purposes.

Democracy at 20? Many (un)happy Returns, [in:] Making Democracy in 20 Years. Media and Politics in Central and Eastern Europe, edit. B. Dobek-Ostrowska, M. Głowacki, Wrocław 2011, p. 15-41.

6 B. Dobek-Ostrowska, Między politologiq i komunikologiq..., „Politeja” 2015, no. 4 (36), p. 34-43; P. Usov, Powstanie, konsolidacja i funkcjonowanie reżimu neoautorytarnego na Białorusi w latach 1994-2010, Warszawa 2014, p. 237-266.

7 B. Dobek-Ostrowska, Między politologia i komunikologiq..., „Politeja” 2015, no. 4 (36), p. 41-43.

8 А. Марков, О. Молчанова, Н. Полякова, Теория и практика массовой информации, Москва 2014, p. 29-30. 
The later development of the printed titles in Russia also largely depended on the government system. It mainly manifested in the following: censorship - through the ban on references to current events, particularly those of social and political nature ( $18^{\text {th }}$ century, the first half of $19^{\text {th }}$ century); lack of legal titles of political parties until 1905; multiplicity of publications of literary nature and their criticism, which, in a way, replaced the pluralism of political thought ${ }^{9}$.

A significant achievement from the perspective of the development of the market of printed press, was Nicolai II's Manifest of October 17th, 1905 on „The improvement of the state order” (Russian: Высочайший Манифест „Об усовершенствовании государственного поря́дка"), also referred to as the first Russian constitution. The manifest spoke of civil rights and political freedoms at the same time creating a good foundation for the establishment of the party press connected with various political environments. Censorship was practically lifted but journalists' criminal liability for press offences was reintroduced ${ }^{10}$. The main outcome of the 1905 Revolution for the Russian publishing market was the development of the legal party and national press (published in the languages of the nations belonging to the Russian Empire). That state of things, however, did not last long and in terms of freedom of expression, it gradually came back to the starting position until 1911. Consequently, the majority of newly established titles (mainly political ones) were forced to join the underground press ${ }^{11}$.

The February Revolution of 1917 in Russia led to the abdication of Tsar Nicolai II and ended the monarchy and the Russian Empire. Eventually, The Russian Provisional Government was set up under Prince Georgy Lvov. Another member who joined the newly formed government was Alexander Kerensky, later the last prime minister of the new parliamentary and democratic Russia. The government announced democratic freedoms, first of all, freedom of speech and press, amnestied political prisoners, legitimized the activity of socialist parties (social democrats, socialists and anarchists) and allowed them to publish their own press. Those changes opened a new chapter in the history of Russian journalism - a short but extraordinarily intensive period of work in the conditions of freedom of press ${ }^{12}$.

In the short period from March to October 1917 (until the Bolshevik mutiny, in the literature referred to as The October Revolution) the journalism had a multi-party

9 Ibid., p. 30-33, 75-85.

10 Journalists could be fined, arrested for the period of up to three months, imprisoned for a year and a half or sent into exile. The General Director of the Press in the Ministry of Internal Affairs and the Police also had the right to confiscate the whole circulation, suspend of the publication or shut down a printing house. Since 1906 the activity of this institution was strictly respected by the government and considerable financial donations were given to the publishing houses acting in favour of the authority. Страницы минувщего. Отечественная публицистика ХІХ - начала XX века, edit. Г. Лапшин, Москва 2017, p. 16.

11 Е. Ахмадулин, Р. Овсепян, История отечественной журналистики ХХ века, Москва 2016, p. 115-129.

12 See: R. Pipes, Rewolucja rosyjska, Warszawa 1994, p. 221-271. 
and multi-national character with a well-defined and diversified nature ${ }^{13}$. In October 1917, the Bolsheviks published 75 magazines while the other parties $-85^{14}$. That diversified system of multi-party press intended for various groups of readers was formed within the period of only eight months of work in the conditions of democratic freedoms and freedom of press. Subsequent incidents of October, 1917 involving fierce fights among the parties, decided on the fate of a number of periodicals containing criticism of the Bolsheviks. As a result, the majority of those periodicals simply ceased to exist after 1918. After the victorious October Revolution, successful actions were undertaken to create the single-party media system and gradually limit the freedom of speech. The ideological party dictatorship in all spheres of life including journalism, fighting dissidents, shut-down of all opposition and private periodicals, monopolization of the publishing market, using the media and information as a political tool - all this defined the Soviet journalism in the first years of Soviet rule and subsequent 70 years of the functioning of the Soviet Union ${ }^{15}$. Thus, the media (the press, radio and television) in the SU played an essential role in creating of the multi-level structure, that is, the Soviet means of information and propaganda (Russian: средства массовой информации и пропаганды ${ }^{16}$. In the mid-1980s, the whole system comprised: in the sphere of print: above 7,500 of all ranks of newspapers, around 2,500 magazines and 114 publications of a various type; in radio broadcasting - 9 national radio channels with the nationwide coverage and 162 local and regional centers; television - The Central SU Television with the regional divisions reaching $95 \%$ of the population ${ }^{17}$. Janusz

13 Richard Pipes wrote about the differences in the nomenclature of the events of February and October 1917 in Russia, that is defining of those two events with the term "revolution": "Although the two events are commonly referred to as revolutions, only the first one really diserves this name. In February 1917,Russia experienced the real revolution because the riots that led to the collapse of tsardom, although not provoked or expected, burst in a spontaneous way and The Provisional Government established as a result of them gained an instant support of the whole country. Nothing like this occurred in October. The events that eventually led to the collapse of the Provisional Government were not spontaneous: they were the result of the coup concluded by a strictly conspired organization. It was only after 3 years of the civil war and absolute terror that the plotters managed to subordinate the majority of the population. October was the example of the classic coup d'état, the interception of the state government by a tiny minority, conducted, due to the democratic conventions of the epoch, in a way that maintained the appearances of the participation of the people but without their engagement. The methods more suitable for the state of war rather than politics were introduced to the revolutionary activities. Ibidem, p. 307.

14 Страницы минувщего. Отечественная публииистика ХІХ - начала ХХ века, edit. Г. Лапшин, Москва 2017, p. 56.

15 А. Марков, О. Молчанова, Н. Полякова, ор. cit., p. 105-106.

16 Seе: М. Шкондин, Система средств массовой информации и пропаганды в СССР, Москва 1986.

17 Е. Ахмадулин, Р. Овсепян, ор. cit., p. 313. It is worth noting that for example a huge number of magazines and newspapers published in that period did not result in the real interest of the Russian society and did not stem from its needs. The system was imposed from the top and majority of citizens had to obligatorily subscribe the main titles or did this out of habit. 
Adamowski pointed out that the SU media system in the mid-1980s was characterized by the following: absolute primacy of the party and government organs over the media; unlimited scope of control by censorship institutions falling under the central power; domination of propaganda and canvassing function of ideological background; strongly centralized structure of the media management based on multi-level structure of the system of means of communication: central, republican, regional and urban as well as district and plant-based ones ${ }^{18}$.

\section{Glasnost and changes in the SU media under Perestroika}

A new era in the history of the country and the development of media in the Soviet Union arrived when Mikhail Gorbachev came to power. Political and economic problems that had piled up for years, clear contradictions between the declared values and lifestyle as opposed to the real processes occurring in the party and the society in general, eventually led to the need to revise the existing policy, including the one relating to propaganda.

Gorbachev took a number of steps in the sphere of the management of mass media and literary magazines (they mainly concerned personal changes), which contributed directly to the introduction of the campaign later referred to as glasnost. Its aim was to criticize the previous model of state socialism, transparency of decision-making process and free access to information ${ }^{19}$. During the $27^{\text {th }}$ Congress of the Communist Party

18 J. Adamowski, Rosyjskie media i dziennikarstwo czasów przełomu (1985-1997), Warszawa 1998, p. 22.

19 As a political term, the word glasnost was used in the period of the Russian Empire. Then glasnost meant the weakening of censorship in the continuous publishing of those days. Later, the term also referred to the issue of transparency in the decision-making process and operation of numerous management bodies. It mainly concerned the courts: under the reforms introduced by Alexander III who wanted to eliminate the term of "the secret of the office" (Russian: "канцелярская тайна"). After the establishment of the USSR glasnost was forgotten until December 5th, 1965. On that day, in Moscow's Pushkin Square the so-called Mityng Glasnosti was held, which was the first this type of event in the Post-war history of the USSR. That political demonstration was organized by the mathematician, Alexander Jasienin-Volpin (Russian: Александр Есенин-Вольпин), the physisist Valery Nikolsky (Russian: Валерий Никольский), the artist Yuri Titov (Russian: Юрий Титов) and his wife Elena Strojevoj (Russian: Елена Строева). Also other Russian dissidents took part in the action, such as: Yurij Galanskov (Russian: Юрий Галансков) i Vladimir Bukovsky (Russian: Владимир Буковский) as well as students, writers and journalists. The demonstration was held to commemorate the USSR Constitution Day, and the main demand of the gathered people concerned the openness of the trials of the literary critic Andriej Siniavsky (Russian: Андрей Синявский) and the poet Yuli Daniel (Russian: Юлий Даниэл). Some protesters were holding the posters with inscriptions such as: "Save the Russian Constitution!" and passers-by were handed in the leaflets prepared by Jesienin-Volpin "Citizens' Call". The total of 200 people took part in the protests in the center of Moscow, but after several minutes the demonstration was chased away by the KGB agents and about 20 people were detained. See: Рефбормы Александра II (кроме земельной). Учебные материаль, http://www.students.chemport.ru/materials/history.htm, inf. of 09.02.2018; 5 декабря 1965 года в воспоминаниях участников событий, материалах самиздата, публикациях 
of the Soviet Union, Gorbachev referred to the period of Leonid Brezhnev's rule as "the epoch of regress" and announced the arrival of a new "era of glasnost "20. In his final speech, the General Secretary of CPSU used a famous phrase - "we need democracy like air". He continued: "Glasnost, criticism, self-criticism are something essential for us today. They are the most important features of a socialist way of life and if someone thinks that we need them only to criticize the mistakes we made in the past - is deeply wrong! The most significant thing is that glasnost, criticism, self-criticism and democracy are necessary for our development, to solve important issues. We will not be able to sort out these issues without active participation of the society.[...] The press must actively participate in this process, must inform the society. However, this must be done in a responsible way, without looking for cheap sensation and something "hot”. We need the press as an active participant of the Perestroika!"21

Undoubtedly, glasnost played a key role in the collapse of the Soviet Union. It turned out that a moment of relaxation and an illusion of novelty were enough for the whole system to start breaking down against Gorbachev's will. In the later period, there were very few things that the General Secretary was able to control: previously forbidden texts started to be printed, journalists became the main characters of the public space and majority of further Gorbachev's actions were merely the reaction to the events nobody could, and in a way, wanted to control.

The process of glasnost involved mainly those spheres of social life that had been strongly censored by the government: literature, cinema and the media. Among others, previously prohibited masterpieces were published: Alexander Solzhenitsyn's "The Gulag Archipelago” (Russian: „Архипелаг ГУЛаг”), Vasilij Grossman’s “Life and Fate” (Russian: „Жизнь и судьба”), Andrei Platonov's “The Foundation Pit” (Russian: „Czewengur”), Yevgeny Zamyatin's “We” (Russian: „Mы”), Mikhail Bulgakov’s “Heart of the Dog” (Russian: „Собачье сердце”), Boris Pasternak's "Doctor Zhivago” (Russian: „Доктор Живаго”), Varlam Shalamov’s “The Kolyma Tales” (Russian: „Колымские рассказы"). Also new texts were published upon the issues which had hitherto been taboo but now started to be lively discussed in various social circles, such as: Tsjingiz Ajtmatov's "Golgotha” (Russian: „Плаха"), Anatoli Rybakov's "Children of the Arbat"

зарубежной прессы и в документах партийных и комсомольских организаций и записках Комитета государственной безопасности в Цк КПСС, red. А. Даниэль, А. Рогинский, http:// memo.ru/index.htm, inf. of 09.02.2018, А. Шубин, Диссиденты, небормалы и свобода в СССР. Тайны советской эпохи, Москва 2008, р. 79-81.

20 One of the breakthrough General Meetings of the Communist Party, the first after Brezhnev's, Andropov's and Chernenko's death (Gorbachev already held the office of the General Secretary of the Central Committee of the Communist Party) and the last but one in the history of the Communist party of the USSR. THE Meeting was held in Moscow in the period from February $25^{\text {th }}$ to March $6^{\text {th }}, 1986$. During the meeting, the party program from 1961 was modified and Perestroika, democratization and ownership were proclaimed.

21 XXVII Съезд Коммунистической Партии Советского Союза, 25 февраля - 6 марта 1986 года. Стенографический отчет, Москва 1986, Volume I, p. 83, 103, passim. 
(Russian: „Дети Арбата”), Vladimir Dudintsev’s “The White Robes” (Russian: „Белые одежды").

Transformations also occurred in the SU film industry. The movies, that had been prohibited for a long time, were made available to the public - Alexander Asoldov's "Commissar” (Russian: „Комиссар”), Kira Muratova's "Brief Encounters” (Russian: „Короткие встречи”), Tengiz Abuladze’s “Repentance” (Russian: „Покаяние”). Meanwhile, the discussion on the rehabilitation of the victims of the Stalinist repressions reemerged. Numerous dissidents were released from prisons and the clergy was slowly regaining their position.

However, the greatest evolution took place in the media sphere. The previously banned issued more and more frequently were presented in the press. The journalists started to write about the time of the Stalinist terror, privileges of the Soviet party nomenclature, bureaucracy, sex and prostitution, environmental problems, etc. Glasnost entered a number of newspapers and magazines representing so-called "Perestroika Press” (Russian: „перестроечная пресса"), including titles such as: “The New World” (Russian: „Новый Мир”), “Моscow” (Russian: „Москва”), “Newa” (Russian: „Нева”), "October” (Russian: „Октябрь”), and above all, illustrated social and cultural weekly "Flash” (Russian: „Огонёк”) and two weekly newspapers- "Arguments and Facts" (Russian: „Аргументы и Факты”), “The Moscow News” (Russian: „Московские Новости" ${ }^{22}$. The journalists employed in the above mentioned periodicals were engaged in the process of transformations and thanks to the-few million circulation, the titles reached a large number of readers ${ }^{23}$.

Television substantially changed its nature. Successively since the beginning of 1986, TV programs started to appear that significantly changed the face of the Soviet television. On February $19^{\text {th }}, 1986$, a breakthrough teleconference "Leningrad-Seattle: The Summit of ordinary citizens" was broadcast. ${ }^{24}$ Average citizens of the two cit-

22 Р. Овсепян,, История новейшей отечественной журналистики. Переходный период (середина 80-x - 90-е годы), Москва 1996, р. 114-117.

23 At that time the most popular newspaper among all press titles was "Arguments and Facts", which was famous for its fight for independence from the central power in 1989. It is worth noting that in March,1990 when its circulation reached 33, 335 copies, "Arguments and Facts" entered the Guiness Book of Records at the first position on the list of the world mass-circulation periodicals. In May, 1990 the circulation of the newspaper reached the record number of 33,431.100 copies and the number of its readers estimated to 100 million. See: J. Adamowski, Rosyjskie media i dziennikarstwo czasów przełomu (1985-1997), Warszawa 1997, p. 37-38.

24 This was already the eighth teleconference between the USSR and the USA but the first one using that format. Alexander Lipkov noticed that the first Russian and American teleconference took place on September 5th, 1982 during the youth festival "We" near Los Angeles. American youth for the first time contacted their peers in the concert studio Ostankino in Moscow. А. Липков, Мость в третье тысячелетие, „Телевидение вчера, сегодея, завтра”, Москва 1987, no. 7, p. 143. Seе more: П. Корчагин, С. Скворцов, В СССР секс был!!! Как мы строили телемосты, Москва 2007; Spacebridges. Television and US-Soviet Dialogue, edit. M. Brainerd, Lanham: University Press of America: Citizen Exchange Council, 1989. 
ies communicated with each other via television signal in the TV studios in the USA and USSR - the two opponents in the Cold War. The program was conducted by the top journalists, Phil Donahue and Vladimir Pozner, who, after the program, became a legend in their own countries. On the day of broadcasting, December $29^{\text {th }}, 1989$, the teleconference was shown by NBC and 70 other TV stations. In the USSR, where all teleconferences were carefully cut, the program was shown only one and a half month later. As Vladimir Pozner recalls: " Teleconference Leningrad-Seattle: the Summit of Ordinary Citizens" was shown on the first channel of the SU National Radio and Television in the prime time not once, but twice. The success was great and unconditional. It was viewed by at least 180 million people. I became a star literally overnight. The will of fate made me become the first Soviet man who, witnessed by the whole country, carried out a spontaneous, non-staged discussion with ordinary Americans. And the fact that I did not lie but instead, noticed weaknesses and problems that Russian citizens knew and understood very well at the same time defending my country's interests in principle matters, was widely publicized in the country. For decades citizens were offered with the TV programs which skillfully omitted any information the government might dislike. Gorbachev called for glasnost, and that teleconference was substantially the first example of it on the TV screen. This TV event was not only my personal breakthrough (it is important to me, but it does not have to be of great importance for the country) but also a historic event"25.

Another ground-breaking event for the Soviet TV was a live broadcast. The first program of this type was broadcast since March $7^{\text {th }}, 1987$ and was entitled: "Before and after Midnight” (Russian: „До и после полуночи”). Before that time only news and sports could be viewed live. Leonid Kravchenko, who then managed The Radio and Television (Russian: Гостелерадио) remembered: "The program strongly stood out due to its new, unique and refined style. Outstandingly intelligent presenter, working in an original way, not imposing his views in an absolute way, but confidentially sharing with you the mystery that touches the most subtle aspects of your soul, breathed life and incredible charm into this program. The dialogue with a smart presenter- interlocutor and a beautiful and witty girl next to him and interesting guests invited to the program - all this was very fascinating. The program provided a lot of new, cognitive and unexpected information"26.

25 In November 2012, in Washington during the conference of the civil society of the US and Russia, Pozner recalling this teleconference said that: "it drew attention of the whole TV audience in the USSR when the choice was limited to only one channel as there were not any other ones." He continued: "I received 77,000 letters in which the two main motifs could be traced. The first one: "Comrade Posner, where did you find those idiots, who were in the studio? Why didn't you invite me as well?" The second motif was in my opinion more important: "I saw my face and I did not like it at all". People felt that they could not be open-minded." See: В. Познер, Прощание с иллюзиями, Москва 2012, р. 207-208.

26 Л. Кравченко, Как я был телевизионным камикадзе, Москва 2005, p. 34; И. Мишина, По ту сторону эфира, Москва 1996; V.Tolz, The USSR in 1989: A Record of Events, Oxford 1990. 
At the end of 1987, the central television and channel one (Russian: OPT) started to broadcast a new program called „The Glimpse” (Russian: „Взгляд”). The program was an attempt of confrontation with the western "radio voices", the jamming of which Gorbachev promised to cease during the meeting with Ronald Reagan in Reykjavik on October $11^{\text {th }}-12^{\text {th }}, 1986$. Since its first edition, the program broke all view records and became a unique symbol of Perestroika. That was a format which completely changed the way in which TV journalism at the end of 1980s was perceived in the context of the transmission of information content. It was conducted by journalists representing the young generation who, in a relaxed and free manner, dressed in casual clothes, presented the information material at the same time producing unique, and frequently quite fierce disputes. In the intervals between those debates, the Western music videos were shown. Due to the absolute ban on broadcasting of music programs with modern foreign music on the territory of the USSR, this was the only opportunity to see and listen to songs of the performers who were at that time popular abroad. That format considerably differed from strongly directed, tightly coordinated and censored information programs shown by the central TV, such as for example, the main news program “Time” (Russian: „Время”). Owing to its form, content and the way of media coverage, the program was, especially for those days, almost revolutionary. Individual editions of the program were connected with social and political events and prominent and recognizable public figures were invited there. The discussions triggered in the program were widely commented on by the public and the media ${ }^{27}$.

According to American political scientist and historian Archie Brown, in spring 1989, officially sanctioned glasnost, turned into practically unlimited freedom of speech $^{28}$. This view was confirmed in the memories of the Deputy of the Highest Council of Latvia, Victor Alksnis, who in 2016 in his interview for the internet portal LENTA.RU recalled: "[...], censorship was practically eliminated. All of the sudden, the society was showered with the wave of TV programs and tabloid press publications in which everything was undermined and turned upside down. As a result, all ideological foundations, on which this country was based were destroyed. People stopped working and instead, they read Moscow News (Russian: "Московские новости"), Ogonyok (Russian: "Огонек") and watched the Glimpse (Russian: “Взгляд")"29. Thus, the initial purposes of the announced glasnost, such as "correction of shortcomings" and "improvement of socialism" started to change quite fast. Increasingly bolder criticism of the regime went beyond those postulates and in its content was in fact closer to the views once stated by the dissidents.

27 Е. Додолев, „Взгляд”- Битлы перестройки. Они играли на кремлёвских нервах, Москва 2011, http://royallib.com/, inf. of 20 III 2018; E. Mickiewicz, Changing Channels. Television and the Struggle for Power in Russia, Durham and London 1999.

28 А. Браун, Горбачев, Ленин и разрьє с ленинизмом, „Полис. Политические исследования” 2007, no. 6, p. 72.

29 «Ни слова о русских оккупантах». Депутат Верховного Совета Латвии Виктор Алкснис о крахе СССР, 25 февраля 2016, https://lenta.ru, inf. of 17 III 2018. 
Summing up the achievements of the period of Perestroika, a few significant aspects characterizing this process shall be mentioned. Firstly, glasnost became one of the most important achievements of Perestroika - the strategy elevated to the status of official state policy. The consequences of the introduction of glasnost policy exceeded not only its founder's and his environment's expectations but also formed the basis for later, democratic changes in the country that had very little experience in this area. Secondly, the printed media became the precursor of the transformations in the media system of the USSR - the fastest and greatest changes took place in the printed media and the journalism obviously turned out to be the main and one of the most significant chains of Perestroika. Thirdly, Perestroika of thinking became the crucial purpose of the media and this substantially changed the nature of journalism as such, as it started to play one of its most basic functions (in democratic countries) - to inform! Fourthly, the dialogue with receivers who literally showered the editorial offices of newspapers, television and radio became one of the core pillar of the media. For the first time, the media presented the information content basing on the reactions of their audiences. Consequently, this lay the ground for a huge credit of trust given to the media and manifested in authentic interest of the society in them and further resulted in multi-million circulations of newspapers and magazines, increased TV audience and real interest in listening to popular radio broadcasts. Citing Janusz Adamowski: "It is not an exaggeration to say that the final years of Perestroika created the strong foundation for the later social authority of the Russian media giving them, in the first period directly after the collapse of the USSR, the real legitimacy of the fourth power" ${ }^{\prime 30}$.

\section{Legislative regulations and development of the media market in 1990}

An important element of transformations of the press market of the late period of the USSR was the act adopted by the Superior Council of the USSR on June 12th, 1990 "On the press and other media" (Russian: "О печати и других средствах массовой информации") ${ }^{31}$. It introduced two principles crucial for the freedom of media: lifting of censorship (article 1- "freedom of the press") and founding pluralism. The new act guaranteed the right to establish newspapers, magazines, radio and TV stations by the councils of people's deputies and other government bodies, political parties, public organizations, citizens' associations, companies and Soviet citizens who reached the age of 18 . According to the new law, the right to cease the publication was reserved exclusively to a founding body or an independent court, which consequently constituted an important guarantee of the functioning of Russian media ${ }^{32}$.

30 J. Adamowski, Rosyjskie media i dziennikarstwo czasów przełomu (1985-1997), Warszawa 1997, p. 43.

31 Закон „О печати и других средствах массовой информации”, http://www.libussr.ru, Закон, inf. of 17 III 2018.

32 „О печати и других средствах массовой информации” 22.10.2013, https://ria.ru, inf. of 17 III 2018. 
This act was substantially valid as a legal ground for shaping of political pluralism of the mass media in the still existing Soviet Union. As a result, in the USSR only in March 1991, there were as many as 1800 nationwide titles registered, a half of which was launched on the market for the first time. 803 of them were still owned by the government institutions but 233 belonged to the editorial teams and separate publishing houses, 291 to various religious organizations and 241 were the property of natural persons. The remaining titles were owned by the joint-stock societies as well as all sorts of companies and cooperatives running business activity ${ }^{33}$.

The act on "The press and other mass media" was in force for only a year and a half. Due to the transformation of political system, in 1991 a new law "On mass media" (Russian: “О печати и других средствах массовой информации”) was adopted already in the Russian Federation ${ }^{34}$. This was a consensual solution in the dispute between the government and the mass media. The act guaranteed freedom of expression, freedom of speech and information dissemination. It also introduced the aspects of the access to information law and in article 3 it stressed the ban on preventive censorship which was a common practice in the previous system. The act was meant to be an important safeguard for the functioning of Russian media in the new conditions of the country's transformation and democratization, which was again confirmed and set out in the provisions of the Constitution of the Russian Federation of 1993. The basic law in article 29 guaranteed freedom of expression and speech, prohibited propaganda and agitation inciting hatred and hostility, forcing to disclose one's philosophy of life and beliefs, or to their renouncing and ensured the citizens' freedom to seek, obtain, pass, create and disseminate the information in any lawful manner. It also guaranteed freedom of mass media and prohibited censorship ${ }^{35}$.

However, this status quo did not last long. Since 1995, the continuing restriction of the media in Russia has been noticeable, especially by the adoption of so-called "media public service laws". The restrictions on the political representation in the media were introduced for the parties exercising the State authority and subsidies and grants were established for the local press in line with the key set out by the State Duma ${ }^{36}$. Thus, increasing power of the government again wished to possess the mass media and exploit them for their own propaganda purposes. It is worth noticing that apart from the political pressure on the media, strong economic instruments of influence on the develop-

33 J. Adamowski, Transformacja rosyjskich środków masowej informacji, [w:] Transformacja systemów medialnych w krajach Europy Środkowo-Wschodniej po 1989 roku, red. B. Dobek-Ostrowska, Wrocław 2002, p. 38.

34 Федеральный закон от 27 декабря 1991 года N2124-1 "Закон о средствах массовой информации", https://rg.ru, inf. of 17 III 2018.

35 „Конституиия Российской Федерации (РФ)”, https://www.zakonrf.info, inf. of 17 III 2018.

36 „Об экономической поддержке районных (городских) газет”, http://pravo.gov.ru, inf. of 17 III 2018; „О государственной поддержке средств массовой информации и книгоиздания Российской Федерации", http://pravo.gov.ru, inf. of 17 III 2018; J. Adamowski, Rosyjskie media i dziennikarstwo czasów przełomu (1985-1997), Warszawa 1997, p. 60-61. 
ment of the media market were introduced as well. For example, thanks to the two legal instruments - the act "On financial support of district (urban) newspapers" (Russian: „Об экономической поддержке районных (городских) газет”) of July $13^{\text {th }}, 1995$ and the act "On the State support of mass media and publishing activity" (Russian: „О государственной поддержке средств массовой информации и книгоиздания Российской Федерации") of October $18^{\text {th }}, 1995$, the government had quite a good possibility to subsidize "appropriate" media operators. These laws introduced the system of state subsidies involving repayable and non-repayable loans or tax reliefs for the publishers appearing on the special list drawn up at the State Duma. Those subsidies were of unquestionable importance for the Russian providers of mass media who were struggling to survive on the already strongly competitive media market. As a result, the desire to raise additional funds from the state in numerous cases contributed to the change of editorial policy into the one which was subservient to the government ${ }^{37}$.

The first half of 1990s in Russia was characterized by a greater consolidation of the political elites around Boris Yeltsin. The so-called August Coup of August 19-21st, 1991 not only accelerated the collapse of the USSR but also led to the actual decline of Communist Party of the Soviet Union.. At the same time, it eliminated the necessity to look for support in the elections and the electoral processes were set back at the statewide and regional level. With social and partly military support, Yeltsin was able to introduce a number of solutions providing the ground for strong presidential power in Russia $^{38}$. After the so-called Constitution Crisis in the years 1992-1993, when Yeltsin's position further strengthened, the process of elite concentration was even greater ${ }^{39}$. This was also an important stage in the development of the Russian mass media, as the process of their dependence on the forefront political forces began at that time. The vast majority of the media supported the incumbent president in that dispute which considerably strengthened his position and his perspective was presented as the only right one in the conflict. That one-sided support granted to the president by the majority of the media was meant to be a symbol of support of democratic transformations in Russia. However, since that moment the process of gradual loss of the newly won freedom of speech and partial support of the society for the media institutions began.

37 See: L. Donaj, Media w systemie politycznym Federacji Rosyjskiej, Poznań 2001, p. 82-83; Ł. Szermiński, System medialny Federacji Rosyjskiej, [w:] Wybrane zagraniczne systemy medialne, edit. J. Adamowski, Warszawa 2009, p. 258; M. Marzec, Współczesny system medialny Federacji Rosyjskiej - wybrane aspekty, „Pisma humanistyczne” 2010, Volume VII, p.167.

38 See: W. Marciniak, Rozgrabione imperium. Upadek Związku Sowieckiego i powstanie Federacji Rosyjskiej, Warszawa 2007, p. 147 passim; A. Skrzypek, Druga smuta. Zarys dziejów Rosji 1985-2004, Warszawa 2004, p. 301.

39 The collection of information in the form of documents, pictures, films, diaries, articles, etc. describing the events of Autumn in 1993 can be found on the website entitled "The October Uprising” (Russian: Октябрьское восстание 1993 года). See: „Октябрьское восстание 1993 года: 21 сентября - 4 октября 1993 г.", http://1993.sovnarkom.ru, inf. of 10 IV 2018. 
Over the subsequent years, political correctness of the media was more and more visible. It resulted from the process of consolidation of political and administrative power with the financial sector in order to take full control over the state for fear of a rollback toward communism and the reversal of the situation fostering such dynamic a dynamic development of the Russian young capital. In the entire operation, the media were used as a means to achieve this goal as they were already financed by the capital groups and consequently, they were almost fully controlled by them ${ }^{40}$. The media dependence on the state power, supported by the financial circles explicitly revealed during the presidential campaign in 1996 and later on that process continued to unfold. As Adamowski plainly stated: "[...] there disclosed, with a powerful force, an absolute dictatorship of the actual owners of newspapers, radio and television; having invested their own capitals, they now demanded full availability of the journalistic teams"41.

It is worth noting that the presidential elections of 1996 became a sort of landmark in the history of the Russian media. The initial absolute support granted to Yeltsin, who fought for the re-election and whose popularity in the country resulting from a number of controversial decisions in the economic sphere and his involvement in the first war in Chechnya was very poor (the drop to the level of 3\%) presented the media (especially electronic ones) as the government tool playing purely instrumental function and having nothing in common with pluralism ${ }^{42}$. Also perception of the media by their receivers changed as the society started to lose confidence in them. The voters who were affected by a large-scale media campaign and thus decided to cast their vote for Yeltsin now felt simply deceived. Especially that it soon turned out that the newly chosen president was in bad health and practically was not able to fulfil his obligations resulting from the Constitutional provisions. The majority of voters admitted that their choice was not appropriate and what is more, they put the blame on the media for that state of things. With regard to those processes, one should agree with Janusz Adamowskis view, who concluded that "in this way, the route of the Russian mass media's travel in search for their identity came to an end", and their political and ideological dependence turned into the economic and political one ${ }^{43}$.

It should be also pointed out that it was already during the time of the first Yeltsin's presidency, and above all, since the moment when the presidential campaign of 1996 commenced that a new steady tendency appeared in the history of the Russian media. If so far their role had been considerable in the political life of the country, it was now becoming almost decisive, which indicated to the emergence of the process of mediatisation of politics and the development of the political media in Russia. The said media-

40 J. Adamowski, Rosyjskie media i dziennikarstwo czasów przełomu (1985-1997), Warszawa 1997, p. 237-239.

${ }_{41}$ Ibid., p. 239.

42 Б. Ельцин, Президентский марафон. Размышления, воспоминания, впечатления, Москва 2008, p. 21.

43 J. Adamowski, Rosyjskie media i dziennikarstwo czasów przełomu (1985-1997), Warszawa 1997, p. 237. 
tisation was a natural consequence of the process of politicizing of the Russian media at the beginning of the 1990s. With new political conditions, their role in the information system became increasingly independent. Tempted by the efficiency of the information technology, the big capital groups started to invest in the media, which consequently led to the emergence of a number of media groups among which almost all central Russian media were distributed. The process of the economic and political dependence became the permanent characteristics of the Russian media market.

\section{Methods of control over the media}

The mass media in Russia under the leadership of president Yeltsin enjoyed a relatively high level of independence from the government. The transformation in this area started with the presidency of Vladimir Putin in $2000^{44}$. The successive years characterized by the limitation of the possibility to criticize the government by the Russian means of mass communication. The negative processes and phenomena in the field of freedom of speech in Russia were not reversed after the election of Dmitry Medvedev for the office of president in 2008 and in fact, became even stronger after Putin's come back to the presidency in $2012^{45}$.

The steps undertaken in order to subordinate the mass media to the political goals of the decision-making center in the Kremlin manifested in the activity at the legal and administrative level and classified activities. Engagement in the implementation of those goals was clearly visible in successive presidential administrations, parliaments, governments as well as bureaucratic and repressive structures of the state. The reason why such a media policy was being carried out in the internal context was to build the personalized authoritarian regime, whereas in the external context it involved the implementation of the program attempting to restore the position of Russia as a superpower $^{46}$.

44 J. Adamowski, System mediów masowych Federacji Rosyjskiej, [in:] Federacja Rosyjska 1991-2001, edit. J. Adamowski, A. Skrzypek, Warszawa 2002, p. 393-436.

45 A. Skrzypek, Druga smuta. Zarys dziejów Rosji 1985-2004, Warszawa 2004, p. 149-159; comp. Putin znów prezydentem. Jak zawsze z przepychem, https://www.tvn24.pl/wiadomosci-ze-swiata,2/ putin-znow-prezydentem-jak-zawsze-z-przepychem,209031.html, inf. of 09.02.2018.

46 Comp. A. Skrzypek, Putinada. Rosja - kraj kierowanej demokracji, Warszawa 2014, p. 174-186; A. Bryc, Putinizm jako doktryna odbudowy imperium?, [w:] Rosja. Rozważania imperiologiczne, edit. S. Bieleń, A. Skrzypek, Warszawa 2015, p. 89-100; M. Domańska, Uzależnieni od konfliktu. Wewnętrzne uwarunkowania antyzachodniej polityki Kremla, https://www.osw.waw.pl/sites/default/ files/pw_67_uzaleznieni-od-konfliktu_net_0.pdf, inf. of 06.11.2017; L. Szewcowa, Nie wolno karmić bestii bez końca, czyli Zachód i Rosja, http://wyborcza.pl/magazyn/1,124059,18547387,liliaszewcowa-nie-wolno-karmic-bestii-bez-konca-czyli-zachod.html, inf. of 14.08.2015; Eksperci o rosyjskiej propagandzie w UE. Percepcja, podatności, prognozy, http://www.cyberdefence24. $\mathrm{pl} /$ eksperci-o-rosyjskiej-propagandzie-w-ue-percepcja-podatnosci-prognozy-analiza, inf. of 30.11.2017; Stalin odchodzi do historii. Rosjanie obojętnieją i zapominaja o represjach, http://www. tvn24.pl/wiadomosci-ze-swiata,2/wiedomosti-rosjanie-coraz-bardziej-obojetni-wobec-represji- 
The more the government tried to defend its influence, the more visible became the manifestation of authoritarianism in Russia. After Putin took over power in Russia, within a few years of evolutionary changes, democratic structures and institutions ceased to fulfil their factual functions and became nothing more but the form of legitimizing of president Putin's and the ruling party's power. This group of a few thousands of people belonging to the circle of closer or further highest rank officials of the administrative, economic and repressive level, or in other words, the presidential center of power, was described in the book by one of the most prominent former spin doctors of the Kremlin, Gleb Pavlovsky, published a couple of years ago entitled: Sistema RF w wojne 2014 goda. De Principatu Debili ${ }^{47}$. The top of this social group ruling Russia is a bit jocosely referred to as "collective Putin". And as assumed by this joke's authors: "individual Putin" will be in power for as long as he will be pursuing "collective Putin's" interests"

The political system developed in Russia may be described as quasi democracy or structural democracy because in spite of the fact that there exist democratic structures, they function in a completely defective way ${ }^{49}$. As a result of legal and administrative measures of the government, a number of political circles lack the possibility to put forward their own candidates. Consequently, the part of electorate is unable to vote for their representatives in accordance with their political preferences. In the model of "hidden autocracy" developed in Russia at the beginning of the 21st century, the balance and mutual control of the three branches of power have also been disrupted. The executive power prevails due to the bureaucratic and repressive apparatus which controls the structures and functioning of the legislative and judiciary branch ${ }^{50}$.

It shall be pointed out that the development of that variant of autocracy, referred to as "autonomous" or "sovereign" democracy by the ideologists in Russia themselves, may be analyzed by indicating to the four areas of the state and social reality that had been functioning on the basis of relative independence from the Kremlin before Vlad-

stalina,742294.html, inf. of 23.05.2017; B. Tesławski, 5 tez Putina z Klubu Wałdajskiego, http://www. eastbook.eu/2017/10/26/5-tez-putina-z-klubu-waldajskiego/, inf. of 26.10.2017.

47 He was removed from the real impact on the Russian media policy due to his objecting to exacerbation of the internal and external policy of the government of the Russian Federation.

48 Comp. K. Rak, Kremlowski książe, www.nowakonfederacja.pl/kremlowski-ksiaze/, inf. of 22 IV 2018.

49 On formal principles of the Russian democracy see: M. Granat, Federacja Rosyjska, [w:] Ustroje państw współczesnych, edit. E. Gdulewicz, Lublin 2005, p. 135-153.

${ }_{50}$ Comp. R. Pipes, The Flight from Freedom, [in:] East and West. History and contemporary state of Eastern studies. Conference, Centre for East European Studies, University of Warsaw, October 26-28, 2008, edit. J. Malicki, L. Zasztowt, Bibliotheca Europae Orientalis XXXIV. Didactica 5, Warszawa 2009, p. 15-24; W. Rodkiewicz, J. Rogoża, Potemkin conservatism. An ideological tool of the Kremlin, Centre for Eastern Studies, Point of View, no. 48, Warszawa 2015, p. 5-6; W. Ross, The Political system of the Russia Federation under Presidents Putin and Medvedev, [in:] Russia of the tsars of the bolsheviks of the new times, edit. J. Malicki Bibliotheca Europae Orientalis XXXIX, Didactica 6, Warszawa 2013; M. Chodorkowski, Będę walczył o wolność, Warszawa 2011, p. 239-241, 254-257; A. D. Rotfeld, Myśli o Rosji ...i nie tylko. Eseje i wywiady, Warszawa 2012, p. 14-16. 
imir Putin's office. They involved: legal opposition parties present in the parliament, civil society organizations operating without the governmental supervision, economic oligarchy independent from the central authority with oligarchs with political ambitions such as Mikhail Khodorkovsky and the mass media, with special attention paid to the TV channels criticizing the central government and free space of the Internet. All those four areas of relative independence were pacified and subordinated to the administrative and repressive structures of the state being at the disposal of the central power ${ }^{51}$.

It is worth noting that the level of freedom of the media's criticism of a government is a very good criterion used to evaluate an actual character of a political system. In only seemingly democratic systems, the supervisory function of the fourth power over the three real branches of power is replaced with the propaganda function. Mass media cease to be the subject in politics and instead, they become a tool used to shape social awareness consistent with the interest of those in power. Exactly this type of transition from the supervisory function of the fourth power to the propaganda one has been taking place in Russia for a decades ${ }^{52}$.

One can indicate a few direct and indirect methods used in the process of subordination of the media system in Russia to its political sphere. The first one involves adopting of acts restricting the supervisory function of the media, that is first of all, the right to criticize the government. Among that type of legal acts, the following could be mentioned: the laws concerning the Internet surveillance prohibiting the publication of memes using the images of public figures or ordering to register blogs visited by more than 3,000 Internet users in the state offices. Another example of the restriction of independence of the Russian media is the act limiting the share of foreign investors in the founding capital of the companies that own media subjects to $20 \%{ }^{53}$.

The second method used by the Russian state involves administrative procedures and persecutions of the media trying to be independent, such as, for example, the activities of the supervisory authority of the media market -Roskomnadzor which terminates the lease and rental contracts of the buildings and rooms that house the editorial offices or increases rents to the level which prevents further functioning of a given me-

51 K. Nieczypor, Kreml napada na internet, http://www.eastbook.eu/2014/04/21/kreml-napada-nainternet/, inf. of 21.04.2014; Rosyjski parlament ogranicza anonimowość w internecie, https://www. tvn24.pl/wiadomosci-ze-swiata,2/parlament-ogranicza-anonimowosc-w-internecie,759794.html, inf. of 26 VII 2017; Rosjanie grożą zablokowaniem Facebooka. „To nie jest serwis wyjątkowy”, http:// tvn24bis.pl/tech,80/facebook-ma-problemy-w-rosji-roskomnadzor-grozi-zablokowaniem,776174. html, inf. of 26 IX 2018; K. Chawryło (Jarzyńska), M. Domańska, Obcy wśród swoich. Organizacje pozarządowe w Rosji, https://www.osw.waw.pl/pl/publikacje/komentarze-osw/2015-09-29/obcywsrod-swoich-organizacje-pozarzadowe-w-rosji, inf. of 29 IX 2018, ; Rosyjskie służby nakazaly zablokować popularny serwis, http://tvn24bis.pl/ze-swiata,75/rosja-blokuje-linkedin-poniewazten-nie-przeniosl-serwerow,691034.html, inf. of 10 XI 2018.

52 T. Piechal, Dlaczego warto oglądać rosyjska propagandę, http://www.eastbook.eu/2014/04/18/ dlaczego-warto-ogl\%c4\%85da\%c4\%87-rosyjsk\%c4\%85-propagand\%c4\%99/, inf. of 18 IV 2018.

53 Media tylko w rosyjskich rękach. Duma wprowadza ograniczenia, https://tvn24bis.pl/ze-swiata,75/ media-tylko-w-rosyjskich-rekach-duma-wprowadza-ograniczenia,472113.html, inf. of 26 X 2018. 
dium; or prompting of technical problems connected with broadcasting of programs or printing of press. At this point, it is also essential to mention some administrative persecutions used towards the operators of cable and satellite networks who were forced to stop the broadcasting of a program in "Dożdi" TV. Moreover, the editors were forced to leave the rented offices on Rozkomandzor's charges of illegal change of address so the program had to be broadcast only via the Internet from the TV station employees' private houses ${ }^{54}$. Other bureaucratic persecutions involved the withdrawal of the press distribution, fiscal inspections and the interpretation of tax regulations that was disadvantageous for the media companies, the withdrawal by the administrative organs of the paid advertisements and commercials, harassment of journalists by cumbersome and lengthy trials resulting from their substantial impairment of the interest of the political and business establishment, limiting of the access to the information for "rebellious" journalists and reporters, the introduction of the complex system of journalists' accreditation in the state institutions, undermining of the independent media prestige by accusing them of the lack of patriotism or not extending of the licenses to broadcast. The perfect example of the last activity was the case of the Crimean TV channel ART which was shut down after the annexation of Crimea in April 2015 $5^{55}$.

Yet another method involved constant intervening into and monitoring by high rank authorities of the contents of news and current affairs programs in the nationwide TV channels controlled by the national companies, which in fact constituted the coordinated national propaganda. A common practice is exerting pressure on the media by phone or written commands of the administrative authorities or summoning of editors in Chief to informal conversations frequently accompanied by threats of being dismissed from work or the means of physical oppression used by the police or other uniformed services. Search and confiscation of the press materials or computer equipment in the editorial offices are another instrument used by the prosecution and the police ${ }^{56}$.

The fourth way involves hostile takeover of the media operators, for example, of the private TV channels belonging to the oligarchs from the Yeltsin period. The first moves of Putin's camp aiming at the suppression of the opponents' resistance involved the elimination of the oligarchs' independence by taking over of the companies controlled by them, such as for instance, Gazprom- Media. In this way the TV stations owned by Vladimir Gusinsky and Boris Berezovski were taken over ${ }^{57}$. Gusinsky was

${ }^{4}$ Niezależna telewizja musi wynieść się ze studia, https://www.tvn24.pl/wiadomosci-ze-swiata,2/ telewizja-dozd-krytykujaca-putina-musi-wyprowadzic-sie-ze-studia,496108.html, inf. of 05 XII 2018.

55 Comp. E. Lucas, Nowa zimna wojna. Jak Kreml zagraża Rosji i Zachodowi, Poznań 2008, p. 110-115.

56 B. Reitschuster, Władimir Putin. Dokąd prowadzi Rosję, Warszawa 2005, p. 117-124; G. Kasparow, Nadchodzi zima. Dlaczego trzeba powstrzymać Władimira Putina i wrogów wolnego świata, Kraków 2016, p. 280-282; A. Głąb, Władza odebrana - media w Rosji, http://www.psz.pl/168-archiwum/ anna-glab-wladza-odebrana-media-w-rosji, inf. of 03 III 2018.

57 Comp. A. Roxburgh, Strongman u szczytu władzy. Władimir Putin i walka o Rosję, Warszawa 2014, p. 88-96; E. Lucas, Podstęp. O szpiegach, kłamstwach i o tym, jak Rosja kiwa Zachód, Warszawa 2014, $166-167$. 
deprived of Media-Most Holding, including then most popular private general-interest channel broadcasting nationwide - NTW and social and political weekly "Itogi". Vladimir Gusinsky left Russia five weeks after the new president took his office at the same time becoming, as Masha Gessen writes in her book entitled "Putin, the man without face", the first "refugee of Putin's regime ${ }^{58}$. Boris Berezovski who left Russia in 2001 was deprived of TV6-Moscow channel ${ }^{59}$.

The sixth way, the use of which may be directly linked to the government, involved the range of illegal activities such as threatening, assaults, beating and killing of journalists ${ }^{60}$. Numerous examples of the above mentioned include several investigative journalists of "Nowaj Gazieta". Yuri Shchekochikhin, liberal lawmaker in the Russian parliament, MP from the party called Jabłoko and member of the Committee of Fighting Corruption was murdered in 2003. He investigated the activity of the Russian special forces. Anna Politkovska shot dead in 2006 was very critical of Vladimir Putin's policy and the Russian intervention in Chechnya. Anastasia Baburova was murdered in $2009^{61}$. Various methods of oppression used against the media have caused changes in the awareness of the journalistic environment. Their main manifestation was the phenomenon of self-censorship ${ }^{62}$.

\section{Propaganda}

The main mass media in Russia, subordinated to the central political power, present political, social and economic content in the propaganda manner. By its definition, propaganda deals with the creation by the mass media of the falsified image of the reality expressed in the information and interpretation messages. It may be said that propaganda is "a distorting mirror" of the reality and its purpose is to manipulate the receivers' consciousness ${ }^{63}$. Its full form can only be observed in non-democratic systems. Firstly because in such systems the most important means of mass communication are personally and substantially controlled by a government, and secondly because there

58 M. Gessen, Putin. Człowiek bez twarzy, Warszawa 2012, p. 169.

59 T. Burrett, Television and presidential power in Putin's Russia, New York 2011, p. 40-71; M. Zygar, Wszyscy ludzie Kremla. Tajne życie dworu Władimira Putina, Warszawa 2017, p. 65-70; W. Paniuszkin, M. Zygar, Gazprom. Rosyjska broń, Warszawa 2008, p. 117-130.

60 A. Politkowska, Udręczona Rosja. Dziennik buntu, Warszawa 2007, p. 137; Rosyjskie media: $w$ żelaznych objęciach Kremla, http://media-w-rosji.blogspot.com/2016/05/rosyjskie-media-wzelaznych-objeciach.html, inf. of 23 V 2018; Niezależny tygodnik dostał ostrzeżenie. Artykuł o Syrii „usprawiedliwianiem terroryzmu”, https://www.tvn24.pl/wiadomosci-ze-swiata,2/tygodnik-thenew-times-ostrzezony-za-usprawiedliwianie-terroryzmu,737236.html, inf. of $05 \mathrm{~V} 2018$.

61 S. L. Myers, Nowy car. Wczesne lata i rządy Władimira Putina, Katowice 2016, p. 405-408

62 Comp. A. Michel, Zaangażowanie polityczne dziennikarzy, [in:] Zmiana $w$ dziennikarstwie $w$ Polsce, Rosji i Szwecji. Analiza porównawcza, edit. B. Dobek-Ostrowska, P. Barczyszyn, Wrocław 2016, p. 129-152; M. Słowikowski, Środki masowego przekazu, [in:] Rosja Putina. Leksykon, edit. A. Głowacki, A. Stępień-Kuczyńska, Łódź 2004, p. 243-245.

63 B. Dobek-Ostrowska, J. Fras, B. Ociepka, Teoria i praktyka propagandy, Wrocław 1997, p. 7-11. 
are no alternative sources of information and current affairs messages, or they reach a very small group of receivers ${ }^{64}$.

The scheme of propaganda process is composed of the following elements: disposers of mass media (politicians who finance and designate the media boards), marketing and media advisors (spin doctors developing a strategy, tactics and operational activities), creators and senders of messages (journalists),propaganda content, technical means of broadcasting, transmission and receiving of propaganda messages and TV viewers, readers, radio listeners and the Internet users.

Propaganda messages in the Russian mainstream state media belonging to the national companies, or the ones being in the possession of oligarchs loyal to the government, may be divided into three categories. The first category of messages reaches the population of Russia (the most numerous group), the second one involves the messages sent to the countries that border Russia and finally the third group of messages is targeted at the recipients in the countries of democratic West ${ }^{65}$. Researchers of the international relationships and media experts identify those measures as the information war with the member states of the European Union and the North Atlantic Treaty Organization ${ }^{66}$. The most important distributors of the propaganda content in the territory of the Russian Federation are the TV channels such as Rassija 1, RTR Płanieta, Pierwyj Kanał and NTW, as well as "Komsomolskaja Prawda" daily ${ }^{67}$. The broadcasts of RT (former Russia Today) TV and the Internet platform Sputnik are addressed to the third category of receivers ${ }^{68}$. They are contradicted to by the few independent media subjects criticizing the government such as "Moscow's Echo", "Nowaja Gazieta" or TV channel "Dożd" 69 .

The content of the propaganda messages result from the political objectives of the Russian Federation. In the internal context, the main task focuses on the maintenance of power by Putin and the United Russia party while in the external context, the most

${ }_{64}$ M. Niewalda Metody manipulacji XXI wieku, Warszawa 2013.

65 Comp. M. Eltchaninoff, Co ma Putin w głowie?, Warszawa 2015, p. 153-161.

$66 \mathrm{~J}$. Darczewska, The devil is in the details. Information warfare in the light of Russia's military doctrine, Centre for Eastern Studies, Point of View, no. 50, Warszawa 2015, p. 5-8; J. Darczewska, P. Żochowski, Active measures. Russia's key export, Centre for Eastern Studies, Point of View, no. 64, Warszawa 2017, p. 5-11.

${ }^{67}$ Comp. A. Włodkowska-Bagan, Rola opinii publicznej i organizacji pozarządowych $w$ rosyjskim dyskursie modernizacyjnym, [in:] Bariery modernizacji Rosji, red. S. Bieleń, A. Skrzypek, Warszawa 2014, p. 165-168.

68 A. Bojke, Władimir Putin. Wywiad, którego nie było, Warszawa 2017, p. 163-173; K. Nieczypor, 300 Putina - medialna armia Kremla, http://www.eastbook.eu/2014/05/06/300-putina-medialnaarmia-kremla/, 06 V 2018; Zdymisjonowany premier Katalonii wystąił w prokremlowskiej telewizji, https://www.tvn24.pl/wiadomosci-ze-swiata,2/byly-premier-katalonii-gwiazda-talk-show-wprokremlowskiej-rt,790942.html, inf. of 17 V 2018; Google walczy z propaganda Kremla. Gigant uderza w portal Sputnik i telewizje RT, http://tvn24bis.pl/ze-swiata,75/google-obniza-pozycjekremlowskich-mediow-w-swoim-rankingu,792018.html, inf. of $21 \mathrm{~V} 2018$.

69 Comp. E. and G. Michalikowie, Rosja, z którą można rozmawiać, Kraków 2016, p. 77-80. 
significant goal is to achieve the position of the key player in the global policy as well as restoring of the Russian influence in the countries bordering with the Federation ${ }^{70}$.

Vulnerability of the majority of Russian society to propaganda and tendency to uncritical acceptance of propaganda messages result from a number of reasons. Firstly, it stems from the heritage of the USSR. At this point, the prevailing sense of injustice among the Russian society shall be emphasized that was caused by the collapse of the Soviet Union and the defeat in the Cold War with the West. The standard of living was very low but people's incomes were safe and moreover, the USSR was one of the two super powers ${ }^{71}$. Secondly, the efficiency of the propaganda messages also results from the positive attitude of the Russians towards president Putin and, at least in the verbal dimension, to Russia's being the world's super power. Thirdly, the traditional Russian detestation of the West which had always exceeded Russia in terms of economic development. The fourth reason is connected with the tradition of tsarist autocracy. Russians had been subject to the absolute power of tsars for ages and in the period of communism that subordination even deepened transforming from the authoritarian to the totalitarian form. Fifthly, Russian people associate liberal democracy and capitalism with the chaos and poverty of the Yeltsin period. Thus, democratic system for lots of modern Russians means simply anarchy and insecurity ${ }^{72}$.

Due to Russians' mentality, their negative experiences from the period of "the second Smuta" [Troubled Times] and current expectations, +-the main assumptions of the Russian state propaganda are as follows: although the living conditions are hard, so long as we are united around our president we will be strong. This is the reason for which everybody respects Russia. The destruction of this unity will cause Russia's weakness and subordination to a foreign capital and this, in turn, will lead to the enslavement of the Russian nation.

Propaganda uses traditional tools known from the handbooks on rhetoric and eristic. For example, argumentum ad ignorantiam is a type of manipulation based on the lack of knowledge of a person who is being convinced. A lie shall have a task of distorting and falsifying of the real image while maintaining the sender's credibility which constitutes the condition necessary for confusion on the part of the receiver. This type comes in several variants. Another kind of argumentation used in propaganda is called argumentum ad populum, that is, "addressing people's tastes" - populism. Manipula-

70 Late Putin. The end of growth, the end of stability, edit. M. Menkiszak, Centre for Eastern Studies, Point of View, no. 55, Warszawa 2015, p. 13-14. Russia penetrates the world and particularly the territory that is perceived as the area of the implementation of its direct interests in the four main ways: collecting of confidential information, propaganda campaigns, infiltration of politicians and political parties and infiltration of economy and finances.

71 Ibidem, p. 23-24; T. Święchowicz, Imperium zła. Reaktywacja, Warszawa 2014, p. 350-377.

72 Comp. J. Darczewska, P. Żochowski, Russophobia in the Kremlins's strategy. A weapon of mass destruction, Centre for Eastern Studies, Point of View, no. 56, Warszawa 2015, p. 5-8; T. Piechal, Rosyjska media przygotowują Rosjan do wojny, http://www.eastbook.eu/2014/03/14/rosyjska-mediaprzygotowuj\%c4\%85-rosjan-do-wojny/, inf. of 14 III 2018. 
tion activities undertaken by the sender rely on the generating of such emotions and strengthening of such stereotypes in the receivers that will help him/her to convince them to his or her views. Yet another type is called argumentum ad verecundiam. In this method a propagandist refers to timidity. It basically concerns the propaganda message containing some authority's point of view that the receiver cannot call into question for various reasons. The fourth type is argumentum ad personam and its goal is to diminish the opponent's credibility and deprive him/her of the receivers trust by attributing to him/her drawbacks, discrediting words or behaviour and even offending or insulting. This has to lead a person to think that his/her views are false. The example of this type of propaganda are the messages concerning the non-parliamentary opposition. The next method is argumentum ad baculum, "the policy of stick and carrot", the message is a threat of distressing consequences in the case when the receiver does not accept the position of the propaganda message sender, or the use of enforcement measures by the propaganda center in order to make an opponent fulfil the expectations of this center. The sixth way called argumentum ad misericordiam, refers to mercy. It involves inciting of compassion, the most frequently not towards a propagandist but rather the third parties. In this case it concerns all who suffer from persecution by the Western countries or allies of the West. Argumentum ad vanitatem, deals with the use of the propaganda message receiver's vanity. It involves an attempt of winning the opponent over by compliments with the hope to make him/her assume the views of the propaganda center. The last of the most popular techniques is a complex and complicated argumentum ad hominem, which is also more difficult to identify than the previous ones. In this technique the sender directly uses the views of the opposing party and assumptions on which they are based to imply false ${ }^{73}$.

The technical construction of propaganda messages cannot be omitted at this point. As Nathalie Grant, one of the researchers of this subject, writes: "this is the combination of what is real, of what majority of receivers want to be real and of what is an obvious false." The example which best illustrates this scheme may be the media campaign accompanying the annexation of Crimea. The first element (the truth): "In the history, Crimea was more strongly bound up with Russia than Ukraine for distinctively longer period of time". The second element (what the receivers would like to see the truth in): "Crimea is to the same extent Russian as Tula and Petersburgh". The third element (false): "Ethnic Russians in Crimea were persecuted by the Ukrainian authorities and needed Russia's support"74.

73 Comp. Leksykon retoryki prawniczej. 100 podstawowych pojęć, edit. P. Rybiński, K. Zeidler, Warszawa 2010, p. 3-6; M. Korolko, Retoryka i erystyka dla prawników, Warszawa 2001, p. 99-107; M. Niewalda, Metody manipulacji XXI wieku, Warszawa 2013, p. 117-122.

74 Dlaczego Rosjanie wierza w Putina? Propaganda stara $w$ treści, nowa w formie https://www.tvn24. $\mathrm{pl} /$ wiadomosci-ze-swiata,2/dlaczego-rosjanie-wierza-w-putina-propaganda-stara-w-tresci-nowa$\mathrm{w}$-formie,466563.html, 14 V 2018; por. J. Darczewska, The anatomy of Russian information warfare. The Crimean operation, a case of study, Centre for Eastern Studies, Point of View, no. 42, Warszawa 
The outcome of propaganda in the Russian society is the fear of imaginary internal and external enemies and suspicion of people and circles representing different views that the one exposed in the state propaganda. Propaganda, enhancing the prevailing position of the United Russia party and Putin's administration, promotes several kinds of content in their media messages. In the internal context, the activities and views of the real opposition situated outside the parliament that negatively evaluates the authoritarian system are criticized. Its representatives are accused of the contacts with the intelligence services of the Western countries and treason of Russia. Also outside-government organizations financed abroad are under the pressure of propaganda being stigmatized by referring to them as a "foreign agent"75. In the context of the historic policy, the period of the USSR and the Stalinist days are no longer explicitly condemned. The special attention should be paid to the fact that some features of the communist regime are now assumed as the positive ones ${ }^{76}$.

In the field of the international policy, the two areas of negative influence shall be indicated. The democratic West, and the United States in particular, are the main object of the creation of the falsified image of the reality. Propaganda messages also concern the countries that wish to become free from the influence of the Russian Federation. Consequently, countries such as Georgia and Ukraine but also Moldova with its ruling elites being adverse to Russia, became the target of propaganda attacks. Since 2013, a special dimension of propaganda has been conducted by the traditional and Internet media in the Russian hybrid war against Ukraine ${ }^{77}$.

2014, p. 5-8; O. Wasiuta, S. Wasiuta, Wojna hybrydowa Rosji przeciwko Ukrainie, Kraków 2017, p. $162-253$.

75 A. Curanović, Sz. Kardaś, Rosja w WikiLeaks, Warszawa 2011, p. 57-60.

76 M. Menkiszak, Russia's best enemy. Russian policy towards the United States in Putin's era, Centre for Eastern Studies, Point of View, no. 62, Warszawa 2017, p. 5-22; M. Mendras, Powrót do oblężonej twierdzy? [in:] Imperium Putina, edit. W. Konończuk, Warszawa 2007, p. 145-160; Gwałtowny wzrost wrogości wobec Ukrainy. Prasa: nigdy wcześniej nie byt tak wysoki, http://www.tvn24.pl/wiadomoscize-swiata,2/rosja-polowa-rosjan-uwaza-ukraine-za-wroga-pisze-rosyjska-prasa,746095.html, inf. of 05 V 2017; Przypominanie o zbrodniach stalinizmu coraz gorzej widziane, http://www.tvn24.pl/ wiadomosci-ze-swiata,2/wiedomosti-przypominanie-o-represjach-stalinowskich-coraz-bardziejniepozadane,745099.html, inf. of 01 VI 2017.

77 O. Szewczenko, Wymiar informacyjny, [in:] Wojna hybrydowa Rosji przeciwko Ukrainie w latach 2014-2016, edit. W. Baluk, M. Doroszko, Lublin 2017, p. 131-152; G. Pilarski, Cyberprzestrzeń narzędzie wojny hybrydowej, [in:] Wojna hybrydowa przeciwko Ukrainie. Wnioski i rekomendacje dla Europy i świata, edit. B. Pacek, J. A. Grochocka, Piotrków Trybunalski 2017, p. 267-281; A. AntczakBarzan, Z. Śliwa, R. Zaniewski, Wojna XXI wieku. Początki wojny „trzeciej fali”, Warszawa 2016, p. 80-85; M. Orzechowski, Wojna hybrydowa jako przejaw neoimperialnego ekspansjonizmu w strategii politycznej Federacji Rosyjskiej wobec Ukrainy, „TEKA Komisji Politologii i Stosunków Międzynarodowych - OL PAN” 2016, no. 3 (11), p. 165-180. 


\title{
Summary
}

Since the beginning of the 21st century, after the period of the apparent hesitation connected with the choice of political system between liberal democracy and authoritarianism, we have been witnessing the gradual establishment of autocracy. As a result, the media system in Russia is developing towards the authoritarian model. Freedom of speech is severely restricted by laws and activities of the governmental administration as well as by decisions of the supervisory authority of the media market. The consequence of this situation is anti-Western and anti-Ukrainian propaganda carried out and skillfully crafted by the main TV channels and the nationwide daily press. Propaganda is a political and media phenomenon that is particularly evident in authoritarian or dictatorial countries. The main media subjects subordinated to the political forces promote the content that is compatible with the government's interest whereas criticism of the government is presented by the media with a rather poor possibility of impact that reach a very small number of receivers.

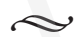

\begin{abstract}
The article analyzes the media system in Russia with respect to a few significant issues. First of all, the basic categorization of media systems has been presented in the perspective of the evolution of political system that situates Russia in the category of the authoritarian models. The main directions of development and specificity of the media space in Russia have been outlined in the historic context. The main tendencies in the subordination of the mass media during Vladimir Putin's office have been described. The factual material analyzed while producing this article gave the grounds to formulate the conclusion that after the period of hesitation in 1990s connected with the choice of political system between liberal democracy and authoritarian system, since the beginning of the 21st century Russia has been experiencing the progressive development of autocracy. As a result, the media system is becoming closer to the authoritarian model. The most significant characteristics of this process include the restriction of freedom of speech, supervision of the media market and increasingly present propaganda.
\end{abstract}

Key words: the Russian Federation, mass media, authoritarianism.

\section{System medialny Federacji Rosyjskiej. Wybrane zagadnienia}

Streszczenie: W artykule dokonano analizy systemu medialnego Rosji przez pryzmat kilku istotnych zagadnień. Przede wszystkim przedstawiono podstawową kategoryzację systemów medialnych w perspektywie ewolucji systemowej, umieszczając Rosję w kategorii modeli autorytarnych. Nakreślono główne uwarunkowania rozwoju oraz specyfikę przestrzeni medialnej w Rosji w kontekście historycznym. Opisano główne kierunki w porządkowaniu mediów masowych w czasach W. Putina. Analizowany w trakcie przygotowania artykułu materiał faktologiczny dał podstawy do wniosku, że po okresie wahania w latach dziewięćdziesiątych XX wieku co do wyboru systemu politycznego pomiędzy demokracją liberalną a systemem autorytarnym od początku XXI wieku w Rosji mamy do czynienia z postępującym kształtowaniem się autokracji, a co za tym idzie system medialny zmierza ku mode- 
lowi autorytarnemu. Najważniejsze przejawy tego procesu to: ograniczenie wolności słowa, nadzór rynku medialnego, coraz bardziej obecna propaganda.

Stowa kluczowe: Federacja Rosyjska, media masowe, autorytaryzm, propaganda

\title{
Медиасистема Российской Федерации. Избранные вопросы
}

\begin{abstract}
Аннотация: В статье анализируется медиасистема России через призму нескольких важных вопросов. Прежде всего представлена базовая категоризация медиасистем в перспективе системной эволюции, относящая Россию к категории авторитарных моделей. Выделены основные детерминанты развития и специфика медиапространства в России в историческом контексте. Описаны основные направления организации СМИ во времена В. Путина. Фактический материал, проанализированный в процессе подготовки статьи, позволил сделать вывод о том, что после периода колебаний в девяностых годах XX века относительно выбора политической системы между либеральной демократией и авторитарной системой, с начала XXI века в России мы имеем дело с поступательным формированием самодержавия, и, как следствие, медиасистема движется к авторитарной модели. Наиболее важными проявлениями этого процесса являются: ограничение свободы слова, контроль за медиарынком, все более распространенная пропаганда.
\end{abstract}

Ключевые слова: Российская Федерация, СМИ, авторитаризм, пропаганда.

\section{Bibliography/Literature}

\section{Thematic publications}

Adamowski J., Rosyjskie media i dziennikarstwo czasów przełomu (1985-1997), Warszawa 1998.

Adamowski J., Transformacja rosyjskich środków masowej informacji, [in:] Transformacja systemów medialnych w krajach Europy Środkowo-Wschodniej po 1989 roku, edit. B. Dobek-Ostrowska, Wrocław 2002.

Antczak-Barzan A., Śliwa Z., Zaniewski R., Wojna XXI wieku. Początki wojny „trzeciej fali”, Warszawa 2016.

Bariery modernizacji Rosji, red. S. Bieleń, A. Skrzypek, Warszawa 2014.

Bojke A, Władimir Putin. Wywiad, którego nie było, Warszawa 2017.

Bryc A., Putinizm jako doktryna odbudowy imperium?, [w:] Rosja. Rozważania imperiologiczne, edit.

S. Bieleń, A. Skrzypek, Warszawa 2015.

Burrett T., Television and presidential power in Putin's Russia, New York 2011.

Chodorkowski M., Będę walczyło wolność, Warszawa 2011.

Comparing Media Systems in Central Europe. Between Commercialization and Politicization, edit. B. Do-

bek-Ostrowska, M. Głowacki, Wrocław 2008.

Curanović A., Kardaś Sz., Rosja w WikiLeaks, Warszawa 2011.

Darczewska J., The anatomy of Russian information warfare. The Crimean operation, a case of study,

Centre for Eastern Studies, Point of View, no. 42, Warszawa 2014.

Darczewska J., The devil is in the details. Information warfare in the light of Russia's military doctrine,

Centre for Eastern Studies, Point of View, no. 50, Warszawa 2015. 
Darczewska J., Żochowski P., Active measures. Russia's key export, Centre for Eastern Studies, Point of View, no. 64, Warszawa 2017.

Darczewska J., Żochowski P., Russophobia in the Kremlins's strategy. A weapon of mass destruction, Centre for Eastern Studies, Point of View, no. 56, Warszawa 2015.

Donaj L., Media w systemie politycznym Federacji Rosyjskiej, Poznań 2001.

East and West. History and contemporary state of Eastern studies. Conference, Centre for East European

Studies, University of Warsaw, October 26-28, 2008, edit. J. Malicki, L. Zasztowt, Bibliotheca Europae Orientalis XXXIV. Didactica 5, Warszawa 2009.

Eltchaninoff M., Co ma Putin w głowie?, Warszawa 2015.

Gessen M., Putin. Człowiek bez twarzy, Warszawa 2012.

Granat M., Federacja Rosyjska, [in:] Ustroje państw współczesnych, red. E. Gdulewicz, Lublin 2005. Imperium Putina, edit. W. Konończuk, Warszawa 2007.

Jakubowicz K., Democracy at 20? Many (un)happy Returns, [in:] Making Democracy in 20 Years. Media and Politics in Central and Eastern Europe, edit. B. Dobek-Ostrowska, M. Głowacki, Wrocław 2011.

Kasparow G., Nadchodzi zima. Dlaczego trzeba powstrzymać Władimira Putina i wrogów wolnego świata, Kraków 2016.

Korolko M., Retoryka i erystyka dla prawników, Warszawa 2001.

Late Putin. The end of growth, the end of stability, red. M. Menkiszak, Centre for Eastern Studies, Point of View, no. 55, Warszawa 2015.

Leksykon retoryki prawniczej. 100 podstawowych pojęć, edit. P. Rybiński, K. Zeidler, Warszawa 2010.

Lucas E., Nowa zimna wojna. Jak Kreml zagraża Rosji i Zachodowi, Poznań 2008.

Lucas E., Podstęp. 0 szpiegach, kłamstwach i o tym, jak Rosja kiwa Zachód, Warszawa 2014.

Making democracy in 20 years : media and politics in Central and Eastern Europe, edit. B. Dobek-Ostrowska, M. Głowacki, Wrocław 2011.

Marciniak W., Rozgrabione imperium. Upadek Związku Sowieckiego i powstanie Federacji Rosyjskiej, Warszawa 2007.

Mendras M., Powrót do oblężonej twierdzy? [w:] Imperium Putina, edit. W. Konończuk, Warszawa 2007.

Menkiszak M., Russia's best enemy. Russian policy towards the United States in Putin's era, Centre for Eastern Studies, Point of View, no. 62, Warszawa 2017.

Michalikowie E. i G., Rosja, z którą można rozmawiać, Kraków 2016.

Michel A., Zaangażowanie polityczne dziennikarzy, [in:] Zmiana w dziennikarstwie w Polsce, Rosji i Szwecji. Analiza porównawcza, edit. B. Dobek-Ostrowska, P. Barczyszyn, Wrocław 2016.

Mickiewicz E., Changing Channels. Television and the Struggle for Power in Russia, Durham and London 1999.

Myers S. L., Nowy car. Wczesne lata i rządy Władimira Putina, Katowice 2016.

Niewalda M., Metody manipulacji XXI wieku, Warszawa 2013.

Paniuszkin W., Zygar M., Gazprom. Rosyjska broń, Warszawa 2008.

Pipes P., Rewolucja rosyjska, Warszawa 1994.

Pipes R., The Flight from Freedom, [in:] East and West. History and contemporary state of Eastern studies. Conference, Centre for East European Studies, University of Warsaw, October 26-28, 2008, edit. J. Malicki, L. Zasztowt, Bibliotheca Europae Orientalis XXXIV. Didactica 5, Warszawa 2009.

Politkowska A., Udręczona Rosja. Dziennik buntu, Warszawa 2007. 
Reitschuster B., Władimir Putin. Dokąd prowadzi Rosję, Warszawa 2005.

Rodkiewicz W., Rogoża J., Potemkin conservatism. An ideological tool of the Kremlin, Centre for Eastern Studies, Point of View, no. 48, Warszawa 2015.

Rosja Putina. Leksykon, A. Głowacki, edit. A. Stępień-Kuczyńska, Łódź 2004.

Rosja. Rozważania imperiologiczne, edit. S. Bieleń, A. Skrzypek, Warszawa 2015.

Ross W., The Political system of the Russia Federation under Presidents Putin and Medvedev, [in:] Russia

of the tsars of the bolsheviks of the new times, edit. J. Malicki Bibliotheca Europae Orientalis XXXIX, Didactica 6, Warszawa 2013.

Rotfeld A. D., Myśli o Rosji ... i nie tylko. Eseje i wywiady, Warszawa 2012.

Roxburgh A., Strongman u szczytu władzy. Władimir Putin i walka o Rosję, Warszawa 2014.

Russia of the tsars of the bolsheviks of the new times, edit. J. Malicki, Bibliotheca Europae Orientalis XXXIX, Didactica 6, Warszawa 2013.

Školany A., Research on Mass Media i Central/Eastern Europe on Southern Europe in Comparative Analysis, [in:] Comparing Media Systems in Central Europe. Between Commercialization and Politicization, edit. B. Dobek-Ostrowska, M. Głowacki, Wrocław 2008.

Skrzypek A., Druga smuta. Zarys dziejów Rosji 1985-2004, Warszawa 2004.

Skrzypek A., Putinada. Rosja - kraj kierowanej demokracji, Warszawa 2014.

Słowikowski M., Środki masowego przekazu, [in:] Rosja Putina. Leksykon, edit. A. Głowacki, A. Stępień-Kuczyńska, Łódź 2004.

Szermiński Ł., System medialny Federacji Rosyjskiej, [in:] Wybrane zagraniczne systemy medialne, edit. J. Adamowski, Warszawa 2009.

Szewczenko 0., Wymiar informacyjny, [in:] Wojna hybrydowa Rosji przeciwko Ukrainie w latach 20142016, edit. W. Baluk, M. Doroszko, Lublin 2017.

Święchowicz T., Imperium zła. Reaktywacja, Warszawa 2014.

Tolz V., The USSR in 1989: A Record of Events, Oxford 1990.

Usov P., Powstanie, konsolidacja i funkcjonowanie reżimu neoautorytarnego na Białorusi w latach 19942010, Warszawa 2014.

Ustroje państw współczesnych, edit. E. Gdulewicz, Lublin 2005.

Wasiuta O., Wasiuta S., Wojna hybrydowa Rosji przeciwko Ukrainie, Kraków 2017.

Włodkowska-Bagan A., Rola opinii publicznej i organizacji pozarządowych w rosyjskim dyskursie modernizacyjnym, [in:] Bariery modernizacji Rosji, red. S. Bieleń, A. Skrzypek, Warszawa 2014.

Wojna hybrydowa Rosji przeciwko Ukrainie w latach 2014-2016, edit. W. Baluk, M. Doroszko, Lublin 2017. XXVII Съезд Коммунистической Партии Советского Союза, 25 февраля - 6 марта 1986 года. Стенографический отчет, Москва 1986.

Zmiana w dziennikarstwie w Polsce, Rosji i Szwecji. Analiza porównawcza, edit. B. Dobek-Ostrowska, P. Barczyszyn, Wrocław 2016.

Zygar M., Wszyscy ludzie Kremla. Tajne życie dworu Władimira Putina, Warszawa 2017.

Ахмадулин Е., Овсепян Р., История отечественной журналистики XX века, Москва 2016.

Ельцин Б., Президентский марафон. Размышления, воспоминания, впечатления, Москва 2008.

Корчагин П., Скворцов С., В СССР секс был!!! Как мы строили телемосты, Москва 2007; Spacebridges. Television and US-Soviet Dialogue, red. M. Brainerd, Lanham: University Press of America: Citizen Exchange Council, 1989. 
Кравченко Л., Как я был телевизионным камикадзе, Москва 2005.

Марков А., Молчанова О., Полякова Н., Теория и практика массовой информации, Москва 2014.

Мишина И., По ту сторону эфира, Москва 1996.

Овсепян Р., История новейшей отечественной журналистики. Переходный период (середина 80-х 90-е годы), Москва 1996.

Познер В., Прощание с иллюзиями, Москва 2012.

Страницы минувшего. Отечественная публицистика XIX - начала XX века, red. Г. Лапшин, Москва 2017.

Шкондин М., Система средств массовой информации и пропаганды в СССР, Москва 1986.

Шубин А., Диссиденты, неформалы и свобода в СССР. Тайны советской эпохи, Moskwa 2008.

\section{Articles in scientific/academic journals}

Dobek-Ostrowska B., Między politologią i komunikologią. Razem czy osobno? Przypadek studiów porównawczych na relacjami polityki i mediów w Europie Środkowo-Wschodniej, „Politeja”, 2015, no. 4 (36).

Marzec M., Współczesny system medialny Federacji Rosyjskiej - wybrane aspekty „ „Pisma humanistyczne" 2010, Volume VII.

Orzechowski M., Wojna hybrydowa jako przejaw neoimperialnego ekspansjonizmu w strategii politycznej Federacji Rosyjskiej wobec Ukrainy , TEKA Komisji Politologii i Stosunków Międzynarodowych - OL PAN", 2016, no. 3 (11).

Браун А.орбачев, Ленин и разрыв с ленинизмом „Полис. Политические исследования" 2007, no. 6. Липков А., Мосты в третье тысячелетие, „Телевидение вчера, сегодея, завтра”, Москва 1987, по. 7.

\section{Internet sources}

„Конституция Российской Федерации (РФ)", https://www.zakonrf.info

„0 государственной поддержке средств массовой информации и книгоиздания Российской Федерации", http://pravo.gov.ru

„0 печати и других средствах массовой информации" 22.10.2013, https://ria.ru

„Об экономической поддержке районных (городских) газет", http://pravo.gov.ru

„Октябрьское восстание 1993 года: 21 сентября - 4 октября 1993 г., http://1993.sovnarkom.ru "Ни слова о русских оккупантах». Депутат Верховного Совета Латвии Виктор Алкснис о крахе СССР, 25 февраля 2016, https://lenta.ru

5 декабря 1965 года в воспоминаниях участников событий, материалах самиздата, публикациях зарубежной прессы и в документах партийных и комсомольских организаций и записках Комитета государственной безопасности в Цк КПСС, red. А. Даниэль, А. Рогинский, http://memo. ru/index.html

Chawryło (Jarzyńska) K., Domańska M., Obcy wśród swoich. Organizacje pozarządowe w Rosji, 29.09.2015, https://www.osw.waw.pl/pl/publikacje/komentarze-osw/2015-09-29/obcy-wsrod-swoichorganizacje-pozarzadowe-w-rosji

Dlaczego Rosjanie wierzą w Putina? Propaganda stara w treści, nowa w formie (14.09.2014), https:// www.tvn24.pl/wiadomosci-ze-swiata,2/dlaczego-rosjanie-wierza-w-putina-propaganda-stara-wtresci-nowa-w-formie,466563.html

Domańska M., Uzależnieni od konfliktu. Wewnętrzne uwarunkowania antyzachodniej polityki Kremla, 06.11.2017, https://www.osw.waw.pl/sites/default/files/pw_67_uzaleznieni-od-konfliktu_net_0.pdf 
Eksperci o rosyjskiej propagandzie w UE. Percepcja, podatności, prognozy, http://www.cyberdefence24. pl/eksperci-o-rosyjskiej-propagandzie-w-ue-percepcja-podatnosci-prognozy-analiza

Głąb A., Władza odebrana - media w Rosji, 03.11.2009, http://www.psz.pl/168-archiwum/anna-glab-wladza-odebrana-media-w-rosji

Google walczy z propagandą Kremla. Gigant uderza w portal Sputnik i telewizję RT, http://tvn24bis.pl/ ze-swiata,75/google-obniza-pozycje-kremlowskich-mediow-w-swoim-rankingu,792018.html

Gwałtowny wzrost wrogości wobec Ukrainy. Prasa: nigdy wcześniej nie był tak wysoki, 05.06.2017, http:// www.tvn24.pl/wiadomosci-ze-swiata,2/rosja-polowa-rosjan-uwaza-ukraine-za-wroga-piszerosyjska-prasa,746095.html

Media tylko w rosyjskich rękach. Duma wprowadza ograniczenia (26.09.2014), https://tvn24bis.pl/ze-swiata,75/media-tylko-w-rosyjskich-rekach-duma-wprowadza-ograniczenia,472113.html

Nieczypor K., 300 Putina - medialna armia Kremla, 06.05.2014, http://www.eastbook.eu/2014/05 /06/300-putina-medialna-armia-kremla/

Nieczypor K., Krem/ napada na internet, 21.04.2014, http://www.eastbook.eu/2014/04/21/kreml-napada-na-internet/

Niezależna telewizja musi wynieść się ze studia, 05.12.2014 https://www.tvn24.pl/wiadomosci-ze-swiata,2/telewizja-dozd-krytykujaca-putina-musi-wyprowadzic-sie-ze-studia,496108.html (09.02.2018).

Niezależny tygodnik dostał ostrzeżenie. Artykuł o Syrii "usprawiedliwianiem terroryzmu”, 05.05.2017, https://www.tvn24.pl/wiadomosci-ze-swiata,2/tygodnik-the-new-times-ostrzezony-zausprawiedliwianie-terroryzmu,737236.html

Piechal T., Dlaczego warto oglądać rosyjską propagandę, 18.04.2014, http://www.eastbook.eu/2014 104/18/dlaczego-warto-og|\%c4\%85da\%c4\%87-rosyjsk\%c4\%85-propagand\%c4\%99/

Piechal T., Rosyjska media przygotowują Rosjan do wojny, 14.03.2014, http://www.eastbook.eu/2014/ 03/14/rosyjska-media-przygotowuj\%c4\%85-rosjan-do-wojny/

Przypominanie o zbrodniach stalinizmu coraz gorzej widziane, 01.06.2017, http://www.tvn24.pl/wiadomosci-ze-swiata,2/wiedomosti-przypominanie-o-represjach-stalinowskich-coraz-bardziejniepozadane,745099.html

Putin znów prezydentem. Jak zawsze z przepychem, 07.05.2012, https://www.tvn24.pl/wiadomosci-ze-swiata,2/putin-znow-prezydentem-jak-zawsze-z-przepychem,209031.html

Rak K., Kremlowski książę, www.nowakonfederacja.pl/kremlowski-ksiaze/

Rosjanie grożą zablokowaniem Facebooka. "To nie jest serwis wyjątkowy", 26.09.2018, http://tvn24bis. pl/tech,80/facebook-ma-problemy-w-rosji-roskomnadzor-grozi-zablokowaniem,776174.html

Rosyjski parlament ogranicza anonimowość w internecie, 26.072017, https://www.tvn24.pl/wiadomosci-ze-swiata,2/parlament-ogranicza-anonimowosc-w-internecie,759794.html

Rosyjskie media: w żelaznych objęciach Kremla, 23.05.2016, http://media-w-rosji.blogspot.com/2016 /05/rosyjskie-media-w-zelaznych-objeciach.html

Rosyjskie służby nakazały zablokować popularny serwis, 10.11.2016, http://tvn24bis.pl/ze-swiata,75/ rosja-blokuje-linkedin-poniewaz-ten-nie-przeniosl-serwerow,691034.html

Stalin odchodzi do historii. Rosjanie obojętnieją i zapominają o represjach, http://www.tvn24.pl/wiadomosci-ze-swiata,2/wiedomosti-rosjanie-coraz-bardziej-obojetni-wobec-represji-stalina,742294. $\mathrm{html}$ 
Pobrane z czasopisma Wschód Europy http://journals.umcs.pl/we

Data: 26/04/2023 11:57:12

Szewcowa L., Nie wolno karmić bestii bez końca, czyli Zachód i Rosja, http://wyborcza.pl/magazyn/1,124059,18547387, lilia-szewcowa-nie-wolno-karmic-bestii-bez-konca-czyli-zachod.html

Tesławski B., 5 tez Putina z Klubu Wałdajskiego, http://www.eastbook.eu/2017/10/26/5-tez-putina-z-klubu-waldajskiego/

Zdymisjonowany premier Katalonii wystąpił w prokremlowskiej telewizji, https://www.tvn24.pl/wiadomosci-ze-swiata,2/byly-premier-katalonii-gwiazda-talk-show-w-prokremlowskiej-rt,790942.html

Е. Додолев, „Взгляд"- Битлы перестройки. Они играли на кремлёвских нервах, Москва 2011, http:// royallib.com/

Закон „О печати и других средствах массовой информации”, http://www.libussr.ru

Реформы Александра II (кроме земельной). Учебные материалы, http://www.students.chemport.ru/ materials/history.html

Федеральный закон от 27 декабря 1997 года N 2124-7 "Закон о средствах массовой информации", https://rg.ru 